\title{
Meiotic and radiation studies in four oligochiasmatic men
}

\author{
E. THOMSON, J. FLETCHER, A. C. CHANDLEY, AND M. KUČEROVÁ \\ From the MRC Clinical and Population Cytogenetics Unit, Western General Hospital, \\ Edinburgh EH4 $2 X U$, Scotland
}

SUMMARY The meiotic findings in four oligochiasmatic males are described. Radiation studiesడ̣̆n the somatic cells of three of them failed to provide evidence for a reduced facility to repair DNA which might also have accounted for the observed failure of chiasma formation at meiosis. The dita support the idea that the 'low chiasma count' condition in sterile men is of mixed aetiology.

Mutants which drastically modify the normal pattern of behaviour at meiosis have been described for a number of species, both plant and animal (see Baker et al., 1976, for review), although no proven example of a human meiotic mutant has yet been found. Several lines of evidence, however, suggest that asynaptic and desynaptic recessive mutations occur in man, the strongest line of evidence coming from the study of meiosis in infertile men exhibiting spermatogenic arrest.

Several authors have described individual cases of phenotypically and karyotypically normal men whose meiotic chromosomes at metaphase I exhibit reduced chiasma counts and an array of abnormal configurations including univalents, large single chiasma bivalents, multivalents, and fragments in some or all cells (Hultén et al., 1970, 1974a; Pearson et al., 1970; Dutrillaux and Guéguén, 1971; Skakkebaek et al., 1973; Chaganti and German, 1974; Koulischer and Schoysman, 1974; Ferguson-Smith, 1976; Templado et al., 1976). At pachytene in the majority of these cases, the bivalents appear to be completely synapsed (desynaptic type), but in two patients, one described by Hultén et al. (1974a), the other by Ferguson-Smith (1976), the formation of the synaptonemal complex was defective and the sex vesicle not identified (asynaptic type).

That some of these effects may have had a genetic cause is suggested by the fact that, in three cases, the men were from consanguineous marriages (Hultén $e t$ al., 1970; Dutrillaux and Guéguén, 1971; FergusonSmith, 1976). In a fourth case, a maternal uncle and

1Present address: Pediatric Department, Postgraduate Medical Institute, Thomayer's Hospital, G2, Prague, Czechoslovakia.

Received for publication 17 November 1978 a maternal male cousin of the patient were $\overrightarrow{a t s o}$ sterile (Chaganti and German, 1974), and in a fof th case (Ferguson-Smith, 1976), two married brothers and one married sister of the patient were atso sterile.

Among the most important generalisations to hâve emerged from the study of meiotic mutants in species other than man is that some, if not all, of the metabolic processes involved in meiotic developmōnt and recombination appear to operate also in somatic cells to ensure chromosome stability, both spontaneously and after irradiation. The relationshiptis illustrated by the many reciprocal observations that mutants affecting chiasma frequency of recombiñ-

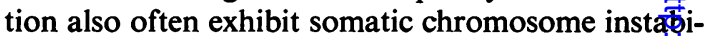
lity, while mutants recovered because they sensitive to irradiation or radiomimetic drugs of en prove to have meiotic effects, particularly on recoinbination (Baker et al., 1976).

The idea that the same biochemical pathwâys could be involved in genetic recombination, repäir replication, and the formation of chromosorgal exchanges (Evans, 1966; Kihlman and Hartley, 1968) has led to studies being undertaken to invesigate the response to irradiation of peripheral blogd lymphocytes or cultured fibroblasts from ' $18 \mathrm{~W}$ chiasma count' men (Adams, 1970; Pearson et 1970; Clarkson, 1972; Ferguson-Smith, 197( $)$. Aberration induction was assessed after $x$-rays, and levels of unscheduled DNA synthesis, indicativeof repair replication were estimated in autoradiograptesic preparations of somatic cells exposed to ${ }^{3} \mathrm{H}$ thyfidine after UV or $x$-rays. In one published case (Pearson et al., 1970), the patient was a man wit a mean chiasma count at meiosis of 9 per cell, who showed germ cell maturation arrest after metaph 
I and resulting azoospermia. The studies showed an approximately $50 \%$ reduction in levels of unscheduled DNA synthesis compared with controls after both UV and $x$-rays, and an aberration yield reduced about $20 \%$ below control levels. The authors suggested that these effects, and the observed failure of chiasma formation at meiosis, could all be accounted for by a reduced facility for repairing DNA in the cells of this particular subject. No other evidence for reduced repair capacity in the somatic cells of an asynaptic or desynaptic man, however, appears to exist. Three other cases, mentioned by Pearson et al. (1970), have been tested for UV and $x$-ray induced unscheduled DNA synthesis and all were found to be normal compared with controls (Adams, 1970; Clarkson, 1972). The case described by Ferguson-Smith (1976) was also normal in respect of response to UV irradiation when tested for unscheduled DNA synthesis (excision repair) (Ferguson-Smith, 1976) and postreplication repair (Lehmann et al., 1977). A fifth case, referred by J. German, in which the meiotic defect showed arrest of prophase at pachytene, also showed normal levels of postreplication repair after UV and normal survival after treatment with $\gamma$-rays, UV, and mitomycin C (Lehmann et al., 1977).

The opportunity to study four more cases of this kind has now arisen in our own laboratory and it seemed important, therefore, to test the response of their somatic cells to irradiation. The four patients, all of whom were phenotypically normal, were ascertained in a systematic study of patients undergoing testicular biopsy for investigation into the causes of their infertility. From one subject to another, they displayed in their spermatocytes at metaphase I a range of chiasma reductions from slightly subnormal to virtually achiasmatic, and in their testicular histology, degrees of spermatogenic impairment ranging from mild to severe. In no case was there reason to believe that exogenous factors were responsible for the meiotic irregularities, and in no case was an obvious abnormality observed in the somatic karyotype.

\section{Case reports and meiotic investigations}

\section{CASE 1. ST 317}

This case was a 32-year-old painter who presented at the Subfertility Clinic in May 1971 after two years of childless marriage. He had two sisters, one of whom was married with a child and the other unmarried, and one unmarried brother. Two seminal samples, taken one month apart, gave a mean sperm count of $8.5 \mathrm{~m} / \mathrm{ml}$, mean motility of $28 \%$, and mean normal morphology of $65 \%$. Histologically, the spermatogenic activity appeared normal and meiotic studies carried out on air-dried preparations showed all stages of spermatogenesis present on the slides. A distribution count on 200 dividing cells was within normal limits compared with findings for control patients (Table 1). No obvious pairing abnormalities were seen in the meiotic prophase stages, but at metaphase I a mean chiasma count of 40.6 per cell was recorded for 26 cells. This was subnormal compared with the normal mean frequency of $50 \cdot 1$ per cell recorded for human spermatocytes (Paris Conference, 1971). In $56 \%$ of cells, the $X$ and $Y$ chromosomes were present as univalents, a factor associated with maturation failure in germ cells (Miklos, 1974; Chandley et al., 1976).

\section{CASE 2. ST 322}

This case was a 26-year-old civil servant, childless for nearly 3 years before presenting at the Subfertility Clinic in August 1971. His wife later became pregnant and a baby was born in 1973 . The patient then remarried in 1974 and returned to the Subfertility Clinic in 1976. Another baby was born later that year to his second wife. He had two unmarried brothers and one unmarried sister. On physical examination, both testes were found to be small, but no other phenotypic abnormality was recorded. The seminal analysis, based on two samples, showed a mean sperm count of $14.5 \mathrm{~m} / \mathrm{ml}$, mean motility of $51 \%$, and mean normal morphology of $68 \%$. Histologically, the biopsy was classified as normal and the air-dried meiotic preparations showed all stages of spermatogenesis on the slides. The distribution count gave evidence, however, for a proportion of cells failing to reach metaphase II compared with controls (Table 1). No obvious synaptic abnormalities were seen at meiotic prophase, but at metaphase I the mean chiasma count was low at $39 \cdot 3$ per cell for the 26 cells analysed. Dissociated $X$ and $Y$ chromosomes were seen in $76 \%$ of 46 cells analysed. Four of these cells also showed a single pair of autosomal univalents.

Table 1 Distribution count of dividing cells seen in meiotic preparations from the 4 cases and 80 control men with normal spermatogenesis (Chandley et al., 1976)

\begin{tabular}{llllc}
\hline & $\begin{array}{l}\text { Spermato- } \\
\text { gonial } \\
\text { metaphase } \\
(\%)\end{array}$ & $\begin{array}{l}\text { Metaphase } \\
I(\%)\end{array}$ & $\begin{array}{l}\text { Metaphase } \\
I \text { ( } \%)\end{array}$ & $\begin{array}{l}\text { Total cells } \\
\text { analysed }\end{array}$ \\
\hline $\begin{array}{l}\text { Case 1 } \\
\text { (ST 317) }\end{array}$ & 8.5 & 55.5 & 36.0 & 200 \\
$\begin{array}{c}\text { Case 2 } \\
\text { (ST 322) }\end{array}$ & 5.5 & 68.5 & 26.0 & 200 \\
$\begin{array}{c}\text { Case 3 } \\
\text { (ST 526) }\end{array}$ & 6.0 & 90.0 & 4.0 & 100 \\
$\begin{array}{c}\text { Case 4 } \\
\text { (ST 537) }\end{array}$ & 31.0 & 67.0 & 2.0 & 100 \\
Controls & 10.9 & 52.8 & 36.4 & 14020 \\
\hline
\end{tabular}


CASE 3. ST 526

This case was a 32-year-old machine operator, married for $5 \frac{1}{2}$ years before presenting at the Subfertility Clinic in February 1977. He had two brothers and four sisters, all of whom were married with children. On physical examination, his left testis was found to be small and the right testis of normal size. A seminal analysis, based on a single specimen, showed a sperm count of $3 \mathrm{~m} / \mathrm{ml}$, motility of $30 \%$, and normal morphology of $14 \%$. The histological report noted that the tubules contained the normal content of spermatogonia and spermatocytes, but complete spermatogenesis was seen in only a small proportion of tubules. Many obviously degenerating primary spermatocytes were seen and few spermatids or spermatozoa were formed. The distribution count showed a severe reduction in numbers of cells reaching metaphase II. Prophase pairing appeared normal in all cells examined, but $\stackrel{\oplus}{a}$ metaphase I there was much obvious degeneration and many univalent chromosomes. A mean chiasna count of 28.1 was recorded for 15 cells which wege still sufficiently healthy to analyse. All showeg dissociated $\mathrm{X}$ and $\mathrm{Y}$ chromosomes, several large single chiasma bivalents, and from one to five paips of autosomal univalents. However, the mean chiasnơ count recorded for this patient was spuriously high owing to the fact that cells with very low chiasna counts and many univalents, which made up the majority, were too degenerate to analyse. A relative? healthy C-banded metaphase $\mathrm{I}$ is shown in Fig. 1. This cell had a chiasma count of about 25 and 4 pairs of univalents including the dissociated XY pair. $\mathrm{C}$-banded metaphase II division is shown in Fig. lib

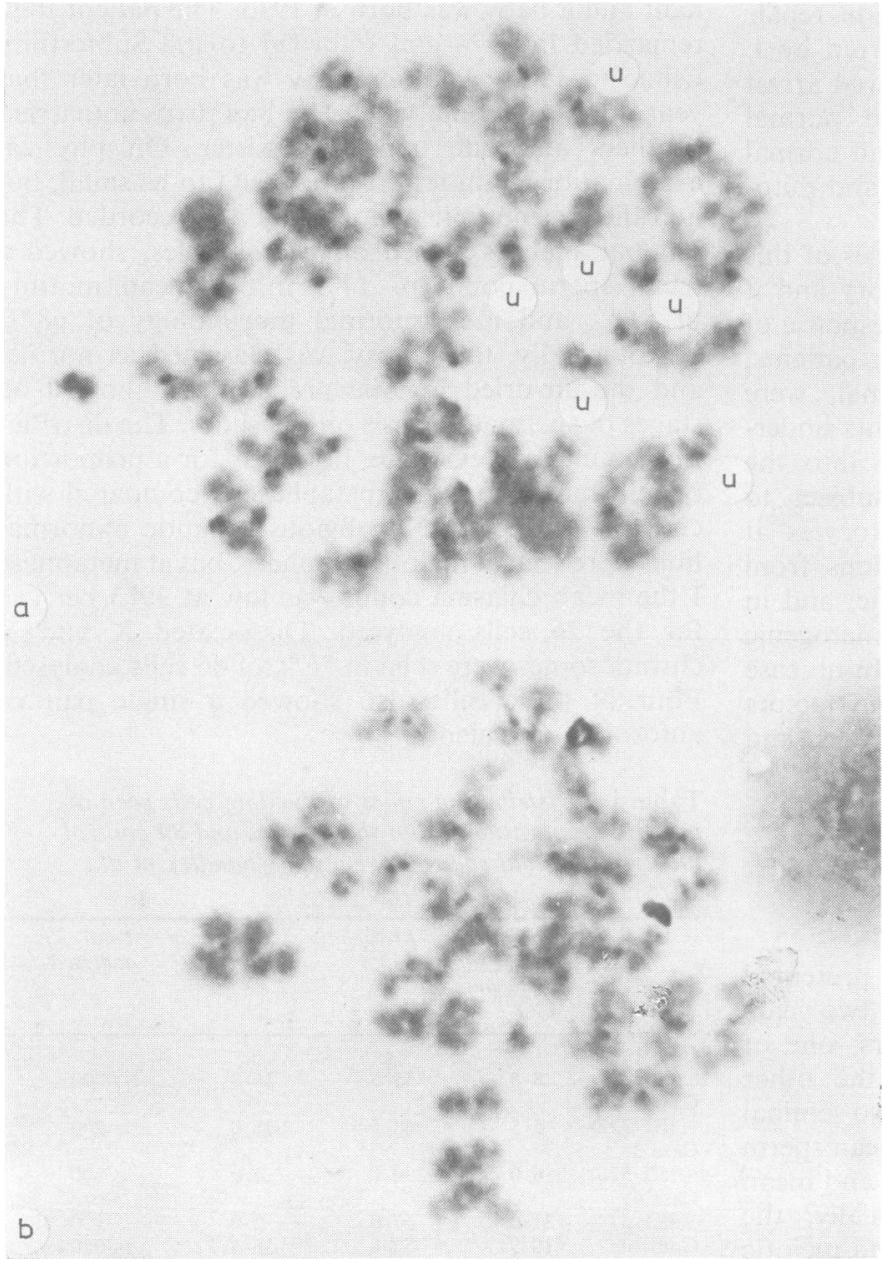

Fig. 1 (a) Metaphase I and (b) metaphase II from case 3. Autosomal univalents are marked $U$. C-banded preparations. 


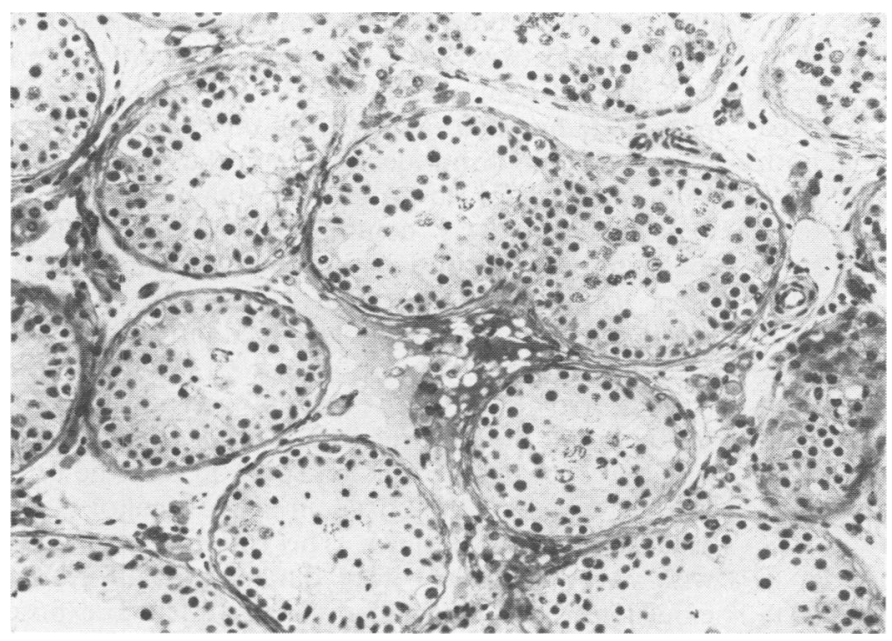

Fig. 2 Histological section of seminiferous tubules from case 4.



Fig. 3 Testicular cells from the air-dried preparations of case 4. a, spermatogonial metaphase; $b$, pachytene; $c$, diplotene; $d$, metaphase I. 
CASE 4. ST 537

This case was a 25 -year-old soldier who presented at the Subfertility Clinic in March 1977 after $3 \frac{1}{2}$ years of childless marriage. He had one brother married with children. Physical examination showed that both testes were small and a seminal analysis based on a single specimen revealed azoospermia. Histolologically, the testicular biopsy showed maturation arrest at the primary spermatocyte stage in the majority of tubules and the presence of spermatozoa in only a minority (Fig. 2). In the air-dried meiotic preparations there was an unusually high proportion of spermatogonial metaphases, but very few cells passed through meiosis to reach metaphase II (Table 1). The spermatogonial metaphases appeared normal (Fig. 3a), as did the majority of pachytene spermatocytes. However, in one or two cells at pachytene, the bivalents displayed synaptic irregularities, the chromosomes showing paired and unpaired segments (Fig. 3b). The appearance of these aberrant human pachytene cells was reminiscent of some of the pachytene spermatocytes we have observed in a male hinny, the sterile hybrid between the horse and donkey. In this animal, a range of pairing irregularities, attributable to parental karyotypic differences, are observed at meiotic prophase (Chandley et al., 1974). At diplotene in case 4 , the bivalents appeared curly and generally desynapsed (Fig. 3c), and at metaphase I the majority of chromosomes were present as univalents (Fig. 3d). The cells appeared virtually achiasmatic and, in the majority of cases, fuzzy and degenerate.

\section{Radiation studies}

To test the response of somatic cells to irradiation, blood lymphocytes from case 2 and from two healthy control males with normal chiasma counts were irradiated with $x$-ray doses of $0,75,150$, and 300 rad. (Blood from case 1 could not be obtained.) Irradiations were carried out in plastic syringes, before culture (GO), using a $250 \mathrm{kV}$ Siemens machine operated at $6 \mathrm{~mA}$ filtered by a Thoraeus filter. The cells were cultured for 48 hours by a modification of the method of Hungerford (1965). Slides were stained with aceto-orcein, coded, and scored blindly by one observer (MK). A total of 100 cells per sample were analysed for dicentrics, rings, and deletions.

Levels of unscheduled DNA synthesis in peripheral blood lymphocytes from the same three patients were assessed autoradiographically after UV exposures of 0,15 , and 30 seconds from a Hanovia low pressure mercury vapour lamp. (Unfortunately, total doses delivered cannot be given, as at the time of conducting the experimentșa record was not kept of the dose rate for the UV lamp:) Exposure of lymphocytes to UV was carried out $\overline{\hat{P}}$ phosphate buffered saline (PBS), the cell suspension forming a 3 to $4 \mathrm{~mm}$ deep layer in the bottom ofo glass petri dish; in order to obtain a uniform exposure, this was continuously stirred with $\mathscr{\bigotimes}_{a}$ magnetic stirrer during irradiation. Immediateby after irradiation, cells were transferred to $10 \mathrm{ml}$ plastic tubes and $3 \mathrm{ml}$ aliquots of medium were addec. For the autoradiography, $10 \mu \mathrm{Ci} / \mathrm{ml}^{3} \mathrm{H}$ thymidinge (specific activity 17 to $25 \mathrm{Ci} / \mathrm{mmol}$ ) was added to the medium and the cells incubated for 2 to 3 hours $37^{\circ} \mathrm{C}$. The medium was then spun off and the cefls washed twice in PBS, fixed in acetic alcohol $(3: \bar{p})$, and air-dried onto slides. The slides were stainef with carbol fuchsin before filming with Ilford $5^{4}$ emulsion. The filmed slides were then left to expose in the dark at $4^{\circ} \mathrm{C}$ for two weeks and developed in Kodak D19B developer for five minutes. Grain count scores were counted independently by two observes, each of whom scored 50 lymphocytes from eash patient. Further blood samples could not be obtained from case 3 or 4 , but skin fibroblasts were culturei from these two patients along with fibroblasts from a fertile control male (chiasma count not known) control female, and a 7-year-old girl with seve manifestations of xeroderma pigmentosum. In the latter case, reduced levels of unscheduled DN synthesis are expected since such subjects exhi a greatly reduced capacity for repairing UV-induced DNA lesions (Cleaver, 1968, 1969). Levels gf unscheduled DNA synthesis after UV doses of 0 , 30, $90,300,900$, and $3000 \mathrm{ergs} / \mathrm{cm}^{2}$ were assessed autoradiographic preparations, which were prepared in a manner similar to that described abede for lymphocytes. All slides were coded and ramdomised before scoring and grain counts over 100 cells were scored at each dose level for each subjest by two independent observers. The numbers heavily labelled S-phase cells in the cultures were algo recorded, and the percentage of cells showing unscheduled DNA synthesis was noted in addition to the grain counts per cell. Attempts were made grow up cells from the fibroblast cultures of cases 3 and 4 in order to test for postreplication reparr after UV irradiation and $\gamma$-ray survival, bog th plating efficiency was so poor that these studies had to be abandoned temporarily (C. Arlett, personal communication). Further attempts are, howev్ㅏ, contemplated.

\section{Results}

The levels of aberration induction in blood lymph cytes after $x$-rays in case 2 and the two controls affe 


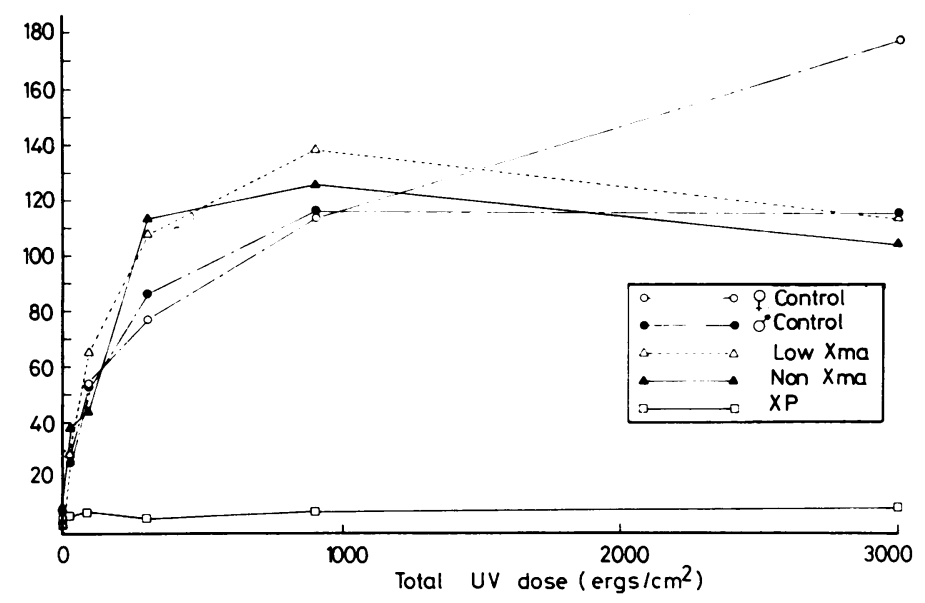

Fig. 4 Mean grain count per cell for cases 3,4 , and controls after $U V$ irradiation and ${ }^{3} \mathrm{H}$ thymidine incorporation. given in Table 2. No significant differences were found from controls. Levels of UV stimulated unscheduled synthesis in these three patients are given in Table 3. There was no significant difference between the case and the controls.

The results of the unscheduled synthesis experiments on fibroblasts from cases 3 and 4 and controls are shown in Fig. 4. Again, no significant differences were detected between cases and controls. Only in the case of the girl with xeroderma pigmentosum were low levels of incorporation of ${ }^{3} \mathrm{H}$ thymidine found and this was expected for this particular condition.

Table 2 Percentages of aberrant metaphases seen in $X$-irradiated peripheral blood lymphocytes from case 2 and 2 control males with normal chiasma frequencies. (100 lymphocytes analysed at each dose for each subject)

\begin{tabular}{llrll}
\hline & \multicolumn{4}{l}{$X$-ray dose (rads) } \\
\cline { 2 - 5 } & 0 & 75 & 150 & 300 \\
\hline Control 1 & 0 & 6 & 26 & 69 \\
Control 2 & 1 & 10 & $\overline{2}^{*}$ & 48 \\
Case 2 (ST 322) & 1 & 8 & 61 \\
\hline
\end{tabular}

*Culture failed.

Table 3 Mean grain count per lymphocyte after UV irradiation and ${ }^{3} \mathrm{H}$ thymidine incorporation for case 2 and controls. (100 lymphocytes analysed at each dose for each subject)

\begin{tabular}{llll}
\hline & \multicolumn{3}{l}{ UV exposure time (sec) } \\
\cline { 2 - 4 } & 0 & 15 & 30 \\
\hline Control 1 & $1 \cdot 1$ & 37.6 & $38 \cdot 7$ \\
Control 2 & $2 \cdot 8$ & $30 \cdot 8$ & $38 \cdot 3$ \\
Case 2 (ST 322) & 1.7 & 38.7 & $32 \cdot 2$ \\
\hline
\end{tabular}

\section{Discussion}

Our negative findings concerning somatic cell sensitivity to irradiation in these particular oligochiasmatic men did not enable us to gain further insight into the possible cause of the meiotic irregularities. It would seem, however, that unlike in the case studied by Pearson et al. (1970), the factor or factors responsible for impaired chiasma formation at meiosis are not involved in maintaining chromosomal stability at mitosis. This could also be said of at least five other cases of this kind which have been studied (Adams, 1970; Clarkson, 1972; FergusonSmith, 1976; Lehmann et al., 1977). It may, of course, be argued that only those subjects showing severe reductions in chiasma frequency at meiosis would be likely also to show mitotic effects. Certainly, in three cases tested for unscheduled synthesis by Clarkson (1972) and in two of our own cases (cases 2 and 3), chiasma frequencies were reduced by only a half or less. However, there still remains our case 4 and the case reported by Ferguson-Smith (1976), both of whom showed a virtually achiasmatic picture at meiosis, but no effects, either spontaneous or radiation-induced, in their somatic chromosomes.

The answer in these cases may lie, however, not in a failure to repair DNA, but in a defect of some other process operating specifically at meiosis along the synapsis/recombination pathway, which has no function in somatic cells. Possible candidates for this role might be zygotene DNA synthesis, or the rprotein/lipoprotein complex, both of which, under normal conditions, ensure orderly synapsis of homologues at meiosis (Stern and Hotta, 1977). Neither appears to function in somatic cells (Hotta and Stern, 1971; Stern and Hotta, 1971, 1977), but 
inhibition of either can result in asynapsis at meiosis (Roth and Ito, 1967; Hotta and Shephard, 1973). A third possibility is the formation or functioning of the enzymes necessary for breakage and repair of DNA to effect meiotic recombination (Howell and Stern, 1971). Failure of nicking or ligation of DNA strands at pachytene could result in the formation of achiasmatic bivalents at meiosis, but since these enzymes appear to function specifically during zygotene and pachytene (Howell and Stern, 1971), their malfunctioning would be expected to produce little or no effect on the somatic elements.

Finally, one interesting corollary to these investigations is provided by a study of meiosis in a man with severe manifestations of the skin condition xeroderma pigmentosum (Hultén et al., 1974b). In the particular case investigated, repair replication after UV light, as measured by levels of unscheduled DNA synthesis in cultured fibroblasts, was greatly reduced compared with normal controls. Meiosis, however, was normal and there was no evidence of defective pairing or impaired chiasma formation in the spermatocytes. This, therefore, provides another situation in which the metabolic pathways operating to repair UV-damaged DNA in somatic cells and those operating at meiosis to ensure normal chiasma formation were independent of each other.

Meiotic studies in other men showing repair defects or chromosomal instabilities in their somatic cells might help to give us clearer insight into the possible operation of common mitotic and meiotic metabolic pathways in man. Further radiation response studies in oligochiasmatic men would also undoubtedly be informative. Such men are rare in the population, however, and opportunities for this kind of study are therefore extremely limited. It does seem likely, however, as previous authors have suggested (Hultén et al., 1974a; Templado et al., 1976), that the 'low chiasma count' condition in sterile men is of mixed aetiology.

\section{References}

Adams, A. C. (1970). The Response of Chromosomes of Human Peripheral Blood Lymphocytes to X-rays. Ph.D. Thesis, University of Aberdeen.

Baker, B. S., Carpenter, A. T. C., Esposito, M. S., Esposito, R. E., and Sandler, L. (1976). The genetic control of meiosis. Annual Review of Genetics, 10, 53-134.

Chaganti, R. S. K., and German, J. (1974). Human male infertility, probably genetically determined, due to defective meiotic pairing and chiasma formation. American Journal of Human Genetics, 26, 19A.

Chandley, A. C., Jones, R. C., Dott, H. M., Allen, W. R., and Short, R. V. (1974). Meiosis in interspecific equine hybrids. I. The male mule (Equus asinus $\mathrm{x}$ E. caballus) and hinny $(E$. caballus $\times$ E. asinus). Cytogenetics and Cell Genetics, 13, 330-341.
Chandley, A. C., Maclean, N., Edmond, P., Fletcher, J., a角 Watson, G. S. (1976). Cytogenetics and infertility in măh. II. Testicular histology and meiosis. Results of a five yęr survey of men attending a subfertility clinic. Annals of Human Genetics, 40, 165-176.

Clarkson, J. M. (1972). Stimulated DNA Synthesis in Hum Leucocytes Following Mutagen Treatment. Ph.D. Thes University of Edinburgh.

Cleaver, J. E. (1968). Defective repair replication of DNA क xeroderma pigmentosum. Nature, 218, 652-656.

Cleaver, J. E. (1969). Xeroderma pigmentosum; a human disease in which an initial step in DNA repair is defectife. Proceedings of the National Academy of Sciences of the USA, 63, 428-435.

Dutrillaux, B., and Guéguén, J. (1971). Anomalies méiotiqựes et gamétiques multiples dans un case de stérilité masculig Annales de Génétique, 14, 49-52.

Evans, H. J. (1966). Repair and recovery from chromoso $\vec{m}$ damage after fractionated $x$-ray dosage. In Genetioal Aspects of Radiosensitivity: Mechanisms of Repair, pip. 31-47. International Atomic Energy Agency, Vienna.

Ferguson-Smith, M. A. (1976). Meiosis in the human mate. In Chromosomes Today, Vol. 5, pp. 33-41, ed P. $\mathrm{Z}$. Pearson and K. R. Lewis. John Wiley, New York.

Hotta, Y., and Shephard, J. (1973). Biochemical aspects colchicine action on meiotic cells. Molecular and Genefal Genetics, 122, 243-260.

Hotta, Y., and Stern, H. (1971). A DNA-binding protein in meiotic cells of Lilium. Developmental Biology, 26, 87-99.

Howell, S. H., and Stern, H. (1971). The appearance of DNA breakage and repair activities in the synchronous meiotic cycle of Lilium. Journal of Molecular Biology, 357-378.

Hultén, M., Eliasson, R., and Tillinger, K. G. (1970). L㞭 chiasma count and other meiotic irregularities in tho infertile 46,XY men with spermatogenic arrest. Heredit $65,285-290$.

Hultén, M., Solari, A. J., and Skakkebaek, N. E. (1974]ु్ర్. Abnormal synaptonemal complex in an oligo-chiasmatyc man with spermatogenic arrest. Hereditas, 78, 105-116.

Hultén, M., de Weerd-Kastelein, E. A., Bootsma, Solari, A. J., Skakkebaek, N. E., and Swanbeck, G. (1974b), Normal chiasma formation in a male with xeroderna pigmentosum. Hereditas, 78, 117-124.

Hungerford, D. A. (1965). Leukocytes cultured from smat innocula of whole blood and the preparation of metaphase chromosomes. Stain Technology, 40, 333-338.

Kihlman, B. A., and Hartley, B. (1968). Effect of hydroxyure and other inhibitors of DNA synthesis on Vicia chromo. somes previously exposed to $x$-rays or to radiomimegc chemicals. Hereditas, 59, 439-463.

Koulischer, L., and Schoysman, R. (1974). Chromosomes aved human infertility. I. Mitotic and meiotic chromosorme studies in 202 consecutive male patients. Clinical Genetidis
$5,116-126$.

Lehmann, A. R., Kirk-Bell, S., Arlett, C. F., Harcourt, S. AJ de Weerd-Kastelein, E. A., Keizer, W., and Hall-Smith, (1977). Repair of ultraviolet light damage in a variety 87 human fibroblast cell strains. Cancer Research, 904-910.

Miklos, G. L. G. (1974). Sex chromosome pairing and ma fertility. Cytogenetics and Cell Genetics, 13, 558-577.

Paris Conference (1971). Standardization in human cytogenetics. Birth Defects: Original Article Series, 8, No. 1972. The National Foundation-March of Dimes, Nef York.

Pearson, P. L., Ellis, J. D., and Evans, H. J. (1970). A gro reduction in chiasma formation during meiotic prophase 
and a defective DNA repair mechanism associated with a case of human male infertility. Cytogenetics, 9, 460-467.

Roth, T. F., and Ito, M. (1967). DNA-dependent formation of the synaptonemal complex at meiotic prophase. Journal of Cell Biology, 35, 247-255.

Skakkebaek, N. E., Bryant, J. I., and Philip, J. (1973). Studies on meiotic chromosomes in infertile men and controls with normal karyotypes. Journal of Reproduction and Fertility, 35, 23-36.

Stern, H., and Hotta, Y. (1971). Meiotic protein in spermatocytes of mammals. Nature, 234, 83-86.

Stern, H., and Hotta, Y. (1977). Biochemistry of meiosis.
Philosophical Transactions of the Royal Society of London, Series B, 277, 277-294.

Templado, C., Marina, S., and Egozcue, J. (1976). Three cases of low chiasma frequency associated with infertility in man. Andrologia, 8, 285-289.

Requests for reprints to Mr E. Thomson, MRC Clinical and Population Cytogenetics Unit, Western General Hospital, Crewe Road, Edinburgh EH4 2XU. 